DOI : $10.15393 /$ j9.art.2008.270

И. А. Айзикова

Томск

\title{
ЕВАНГЕЛЬСКИЕ ИДЕИ, МОТИВЫ, ОБРАЗЫ В «СВЯТОЙ ПРОЗЕ» В. А. ЖУКОВСКОГО
}

Религиозность В.А. Жуковского, первого русского романтика, на разных этапах жизни и творчества носила разный характер, проявляясь в разных планах (философском, эстетическом, социально-историческом) $)^{2}$, но главным был тот нравственный идеал, который Жуковский, как и многие его современники, в первую очередь Н. В. Гоголь, нашел для себя в Новом Завете, в его идеях и образах, в образе Иисуса Христа. Всю жизнь направлявший свое внимание к «внутреннему человеку», с его неповторимостью и индивидуальностью, и одновременно пытавшийся постичь универсальные смыслы происходящего с личностью и миром, поздний Жуковский соединяет эти две линии своего творчества, и точкой их соединения оказывается Христос. Наиболее полно это проявилось в прозе Жуковского 1840-х годов, которую он сам назвал «святой». Тексты этих произведений, выстроенные на идеях Священного Писания, отличаются особой поэтикой, они пронизаны библейскими цитатами, образами, мотивами. Причем на первом плане у Жуковского оказывается именно Евангелие, в центре которого воплощение Сына Божия в человеческом образе.

\footnotetext{
(C) Айзикова И. А., 2008

${ }^{1}$ Статья подготовлена при финансовой поддержке РГНФ (проект № 03-04-00251a).

${ }^{2}$ См. об этом подробно в кн.: Канунова Ф. 3., Айзикова И. А. Нравственно-эстетические искания русского романтизма и религия (1820-1840-е годы). Новосибирск, 2001.
} 
Том «святой прозы» задумывался Жуковским для Полного собрания сочинений, оказавшегося последним прижизненным ${ }^{3}$ как «цикл циклов» прозаических фрагментов не всегда ясной жанровой природы. Попутно заметим, что обращение в 1840 -е годы и к фрагменту, и к циклизации для писателя очень характерно: с одной стороны, реализуется построение субъективной картины мира без последовательных причинно-следственных связей, с другой - установка на целостность, собирание из отрывков целого, реализация идеи синтеза, которая стала сквозной в позднем творчестве Жуковского и многих других русских писателей и мыслителей 1840-х годов.

«Святая проза» Жуковского вся построена на мысли о Христе как неоспоримой, вечной истине, определяющей бытие человека. При этом именно в поздней прозе Жуковский заостряет, как никогда ранее, проблему внутреннего и внешнего согласования человеческой жизни с Христом, вопрос о соотношении свободной воли личности и божественного предопределения, в связи с чем актуализируются и по-новому освещаются такие проблемы всего творчества писателя, как духовный путь человека, идея жизнестроения. Эта направленность авторского сознания к Богу, стремление Жуковскогохудожника не к логике, а к художественности, к охвату действительности и человека во всей их полноте обусловили установку писателя на прорыв к универсальному, метафизическому плану текстов и, соответственно, на формирование новых принципов поэтики, реализующихся на разных уровнях их повествовательной структуры. 
Прежде всего обратимся к образу Христа, который отличается необычайной многоплановостью в «святой прозе» Жуковского. В первую очередь, образ Спасителя неизменно связывается Жуковским с идеей любви к человеку, проявляющейся прежде всего в том, что «Спаситель, то есть Бог любящий» может «научить человека предаться

\footnotetext{
${ }^{3}$ Речь идет о кн.: Стихотворения Василия Жуковского: В 13 т. 5-е изд. Т. І-ІХ. СПб., 1849. Т. Х-ХШ. СПб., 1857. «Святая проза» при жизни Жуковского так и не была опубликована ни в составе ПСС, ни в каком другом издании. Она вошла, не полностью, с купюрами, в посмертные тома X, XI. O подготовке своей «святой прозы» к печати Жуковский вел активную переписку с П. А. Плетневым. См.: Сочинения и переписка П. А. Плетнева. СПб., 1885. Т. 3.
}

170

Богу Создателю, то есть Богу Отцу и дать Ему истинное, исключительно Ему принадлежащее имя Отца, сущаго на небеси» ${ }^{4}$. Не случайно статья «Вера» построена именно вокруг образа Христа, проливающего свою благодать на возводящих «мост через бездну, которою отделена верующая душа от Бога» (XI, C. 4). Именно Бог Сын учит людей своим примером не только «признанию» Бога, но и «преданию себя» в Его волю, помогая тем самым приобрести «полную веру». Такая вера выражается, по убеждению автора, «не одною мыслью, но и делом», «или правильнее, - уточняет Жуковский, - дела с нею (мыслью. - И. А.) неразлучны» (XI, С. 4).

Мысль о Христе как о посреднике между Богом и человеком в стремлении последнего к вере проходит и через статьи «О внутренней христианской жизни», «Таинство причащения» и др. Рассуждая о сути «присутствия Божия», о «соединении души с Богом», Жуковский признает абсолютную непостижимость Бога, во многом по причине Его «невоплощенности», 
«невообразимости», а с другой стороны, он утверждает идею Христа, в котором обитает полнота Божества телесно, «в Котором все земное, прекрасное, драгоценное, чистое слилось и божественно преобразилось, дабы недоступный, непостижимый, неизглаголанный Бог вселенныя сделался сокровищем, собственностью, ясным предметом любви и собеседником всякой души человеческой» (X, С. 134). Вывод отсюда делается весьма однозначный - «в сие присутствие (Бога. - И. А.) он (человек. - И. А.) может быть введен только Христом. Бог сошел во Христе к человеку, человек только Христом может возвыситься к Богу» (X, С. 133). Не случайно в статье «О внутренней христианской жизни», рассуждая об искуплении как о «возвращении человеку утраченного им присутствия Божия», Жуковский вспоминает переданные евангелистом Иоанном слова Христа из Его заповеди ученикам, которую он произнес в Гефсиманском саду, незадолго до своей смерти: «Аз есмь путь» (гл. ХTV, ст. 6).

$\mathrm{C}$ точки зрения Жуковского, степень ясности человеческого понятия о Боге зависит именно от веры человека в Христа, в связи с чем автор различает «философического, умственного, из нашей идеи извлеченного Бога», к которому невозможно испытывать «живую любовь», и «Бога

\footnotetext{
${ }^{4}$ Жуковский В. А. Полн. собр. соч.: В 12 т. СПб., 1902. Т. Х. С. 79 (из статьи «О молитве»). В дальнейшем, цитируя по этому изданию, в тексте указываю том и страницу.

откровенного, чрез Христа Спасителя вошедшего в нашу жизнь» (X, С. 133). Лейтмотивом по всей «святой прозе» Жуковского проходит мысль о том, что «в Христе Бог всемирный приближается к человеку братом, отцом... и
} 
все сии имени не уничтожая Его неизглаголанного, всемирного величия, делают Его человечески приблизимым, и душа, приближаясь к Нему, Его видит, слышит, чувствует, объем лет и любит».

Эта возможность внутреннего ощущения присутствия Бога является для Жуковского главным, поскольку в противном случае человек или создает себе идола, делая Бога «материально доступным», или впадает в атеизм, в «метафизическое безверие», превращая Бога в «отвлеченное понятие» (X, С. 134). Собственно поклонение «философическому Богу», считает Жуковский, есть поклонение человека самому себе. Для создания образа «умственного Божества» Жуковский не жалеет красок: он «сшит», по выражению автора, «нашим умом из клочков», это «одна проблема, заданная умом». Всякий раз подчеркивается именно отсутствие целостности мировидения и мироотношения, вытекающее из «веры» в «умственного идола» (Х, С. 136). Образ «откровенного Бога» создается с помощью эпитета «живой», то есть, по мысли Жуковского-романтика, производящий «впечатления на душу».

Не случайно столь пристальное внимание Жуковского к одному из семи таинств православной церкви - к причащению, благодаря которому верующие становятся «стелесниками Христа», и к литургии, во время которой это таинство совершается. Раздел «целого тома святой прозы» Жуковского - «Христианская философия» завершается специальной статьей, которая так и называется «Таинство причащения». Жуковский относится К этому «таинству таинств» как к «высочайшему, всеобъемлющему, блаженнейшему делу нашей земной жизни». Суть причащения автор видит именно в том, что человек «на мгновение становится лицом к лицу перед самим Богом, и этот оживотворяющий взор, устремленный от человека на 
Бога и от Бога на человека, преображает душу во мгновение, все ее прошедшее исчезает в блаженной чистоте настоящего; она некоторым образом ощущает самую вечность» (XI, С. 12).

Причащение Жуковский называет свиданиями человека с Христом, а через Него с Богом.

В промежутках этих великих, главных эпох жизни, этих животворящих соединений, человек остается человеком, слабым,

\section{2}

зависящим от влияния внешнего, рабом своих слабостей, бедным наследником греха первобытного.

Минуты подготовки к причащению и самого таинства «суть минуты святые», соединяющие «земное с небесным», пишет Жуковский (XI, С. 12). Причащение, по убеждению автора, это некий поворотный момент в жизни человека, когда он «начинает идти к другому путем обыкновенной жизни» (XI, С. 12).

Вместе с тем Жуковского волнует и проблема вочеловечивания Абсолюта в Христе. Размышляя над вопросами, «что такое присутствие Божие», «что такое соединение души с Богом» (X, С. 132), писатель обращается к одному из важнейших событий из жизни Христа - к преображению, о котором рассказывается в Евангелии от Луки. Как известно, во время молитвы с учениками на горе Фавор человеческое тело и лицо Христа «преобразились, сияли, как солнце, одежды Его блестели, как свет, и на глазах удивленных учеников на гору спустилось облако, из которого раздался голос Бога, свидетельствующий о том, что Христос - Его сын возлюбленный».

Жуковский подчеркивает в этом евангельском сюжете, по крайней мере, две идеи - таинственность, 
мгновенность и непостижимость произошедшего реального действия и избранность присутствовавших при преображении Иисуса, испытавших «сладчайшее чувство частного бытия, погруженного в божественное, без всякой примеси чувственного, без всякого воспоминания о земном обладании. <..> В этом чувстве нет ничего ни внешнего, предметного... ни личного... в нем соединяется и то, и другое, в какой-то необъяснимой для нас неопределенности, в какой-то неограниченной полноте, ясное, но вместе и непостижимое и невыразимое» (X, С. 133). Выразить это «невыразимое» и призваны в статье Жуковского «О внутренней христианской жизни» евангельский мотив преображения Господня и связанные с ним образы света, вершины Фавора и его подошвы, избранных апостолов. Преображение Спасителя, в изображении Жуковского, «совершилось мгновенно на вершине Фавора для избранных апостолов и разлияло свет свой на всю их жизнь, проводимую у подошвы горы, посреди забот житейских. Иди за Спасителем на вершину горы Фавора, озарись светом Его преображения, но на ней ты остаться не можешь» (X, С. 133).

Развитие мотива вочеловечивания в Христе Абсолюта постоянно сопровождается у Жуковского попытками решить один из главных вопросов всего его творчества о соотношении божественной воли (необходимости) и свободы нравственного выбора человека. Различая личную и гражданскую свободу, Жуковский преимущественно говорит в своих поздних статьях о «свободе в высшем смысле», которая есть, с его точки зрения, «совершенная подчиненность воле Божьей, всегда, во всем, везде» (Статья «Свобода»; XI, С. 22). 
Сущность этой подчиненности автор видит в «свободе от зла». При этом он считает, что «естественный нравственный закон» недостаточно ясен, четок, а «голос совести», внутреннее выражение этого закона, «хотя и всегда слышен, но не всегда внятен» (XI, С. 22). Только учение Христа, Его заповеди, обращенные к «нищим духом» и «плачущим» о своих грехах, не дают совести «заблуждаться».

Эта мысль неоднократно повторяется Жуковским в его «святой прозе» (см., например, «Две сцены из "Фауста"», «О внутренней христианской жизни»), причем довольно часто она возникает в связи с размышлениями о свободе общественно-политического плана (напр., статьи «О меланхолии в жизни и в поэзии», «О происшествиях 1848 года», «Человек в обществе», «Самодержавие»). В указанных статьях писатель настойчиво отрицает революцию как мнимое освобождение, как действие, произведенное вследствие внешней необходимости, а не свободно творящей волей. Так, в статье «О происшествиях 1848 года» Жуковский развивает мысль о том, что «мнимые освободители» «для того провозглашают свободу, самодержавие народа... независимость мысли и слова», чтобы только «украсить мятеж» (X, C. 117).

Проблема мнимой свободы, даруемой революцией, проходит через всю статью «Что будет?». «Это всеобщее отвержение всякой святыни называется теперь свободою, движением вперед, торжеством человечества, освобождением разума», - восклицает автор (X, С. 139). Особенно опасна такая «свобода», считает он, для «низшего класса». Для «народа необразованного», где царствуют нужда, зависть, озлобление, такая «свобода» - настоящее искушение, разжигающее самые низкие страсти, самообман, ведущий к бездне. За всем 
этим стоит неприятие Жуковским индивидуализма, разъединенности, раздробленности духовного

\section{4}

го мира людей, подчинения духа материи, что связано, по его убеждению, с губительным для человека торжеством рационализма, усиливающегося отходом от религии. В очерке «Иосиф Радовиц» Жуковский прямо назовет революцию и все ее «так называемые благоприобретения» ложью. Истинная свобода пробуждает в каждой отдельной личности и в народе в целом «законное стремление к единству, то есть к соединению всех членов в одно крепкое тело для дарования этому телу живой силы, с сохранением самобытности каждого члена отдельно» (XI, С. 49). Образ свободного народа как единого живого тела оттеняется в другой статье - «О происшествиях 1848 года»страшным образом «уродливого трупа, у которого... остались только ноги для того, чтобы все слепо топтать с необузданным бешенством» (X, С. 119).

«Мнимой свободе» Жуковский неизменно противопоставляет утверждение нравственной свободы, которой не может быть без веры и смирения человека перед Богом и его волей и которая является прочным фундаментом общественного прогресса. В письме наследнику престола от 29 января 1849 года Жуковский, сравнивая Великую французскую революцию и «теперешнюю», прямо пишет о том, что «та революция, которая бесится перед глазами нашими, есть не иное что, как отвратительное детище эгоизма» ${ }^{6}$. И вместе с тем Жуковский признает, что именно внутренняя свобода человека толкает его к тому, чтобы «отделить себя от общего», чтобы «творить для себя свою особенную совесть» и, «не видя вокруг себя добра существенного, создавать... добро химерическое и действовать по 
произволу» (Х, С. 138). Особенно часто это происходит «во времена смутные, во времена волнений гражданских и религиозных, в которые распространяется повсеместно какая-то вулканическая деятельность, не имеющая ясного предмета» (X, С. 137). Здесь слышатся интонации пушкинской и лермонтовской поэзии и прозы, а также романов Достоевского и Толстого.

Проблема свободы нравственного выбора человека («энтузиазм») напрямую связывается Жуковским с комплексом религиозно-философских проблем, которые станут важнейшими в русской литературе начиная с 1830х годов. Это вопрос о культе сильной личности и обращение в связи с этим к проблеме наполеонизма, к идее двойной морали

\footnotetext{
${ }^{5}$ Русский архив. 1885. № 4. С. 529.
}

и вытекающей из нее вседозволенности, вплоть до посягательств (с благими намерениями) на перестройку созданного Богом мира и природы человека. Словно уже прочитав роман Достоевского «Преступление и наказание», Жуковский пишет о том, что «сие страстное, ничем не обуздываемое стремление к идеальному благу» и «есть отличительный характер энтузиазма, который и в самом благом направлении может быть источником великих злодеяний, при недостатке ясных, положительных правил нравственности, легко затемняемых софистическими умствованиями страсти» (X, C. 138).

Единственной силой, способной вернуть человека на землю, отвратить его от абстракций к реальности, от теорий и идей к натуре человека и действительности, от «мечтательства» к «обыкновенности» признается вера в Христа, которая диктует одну для всех нравственность, не 
ломающую, а, напротив, укрепляющую личность. «Я выше всего ставлю эти так называемые обыкновенности, - Читаем мы в статье «О стихотворении "Святая Русь"», — они в языке и в жизни то же, что воздух, невидимо нас окружающий. .. То, что вошло в обыкновенность, принято всеми, для всех неотрицаемо; оно потеряло свою новость от своей давности, но по тому самому и есть всеобщая необходимая истина. Оно приобретает вдруг характер какого-то откровения, чудно выражающего истину верховную» (Х, С. 121).

Наряду с идеей покорности воли Божьей, смирения важнейшую роль в понимании человека у Жуковского играет мысль об искуплении греха страданием. Во многих его статьях 1840-х годов это некая новая точка отсчета в жизни человека, начало решения всех проблем, путь к бессмертию души. С этими идеями тесно связана философия скорби Жуковского, наиболее полно изложенная в программной статье «О меланхолии в жизни и в поэзии», которая, как известно, первоначально представляла собой письмо П. А. Вяземскому от 3 (15) марта 1846 года ${ }^{6}$. Главная тема статьи меланхолия ${ }^{7}$. Стремясь к полноте

\footnotetext{
${ }^{6}$ Об истории создания и публикации статьи см.: В. А. Жуковский. Эстетика и критика. М., 1985. С. 418.

${ }^{7}$ См. работы И. Виницкого: Радость и печаль в жизни и в поэзии В. А. Жуковского // Известия РАН. Сер. лит. и яз. 1996. Т. 55. № 5; Утехи меланхолии // Уч. зап. Московского культурологического лицея. Вып. 2. М., 1997. См. также: Долгушин Д. В. В. А. Жуковский и И. В. Киреевский: к проблеме религиозных исканий русского романтизма: Автореф. дис. ... канд. филол. наук. Томск, 2000. С. 18 19.
} 
176

и целостности ее осмысления, Жуковский сталкивает в статье два голоса, две точки зрения - свою и Вяземского. Статья даже композиционно выстраивается как диалог. Начинаясь с отрывка письма Жуковского И. В. Киреевскому о переводе «Одиссеи», которое было опубликовано в «Москвитянине», она продолжается второй частью «Замечания на письмо», представляющей собой ответ Вяземского на «поэтическую исповедь» Жуковского, который, в свою очередь, в статье «О меланхолии...» получил «Ответ на замечания».

Тема меланхолии таким образом не только укрупняется, но приобретает глубоко диалогическое звучание. Меланхолия в понимании Вяземского есть чувство уныния, которое совершенно одинаково переживали как в языческом Древнем мире, так и в мире христианском. С приходом христианства и осознанием бессмертия души чувство тоски усугубляется страданием, земная жизнь перестает представлять для человека ценность. Вероисповедание современного мира Вяземский определяет так:

Смерть начало всего...

...на жизнь смотришь как на лоскуток чего-то, как на программу, как на лотерейный билет, не зная, что вынется (X, C. 99).

Жуковский, возражая Вяземскому, во-первых, разводит понятия меланхолии и уныния. Уточняя дефиниции Вяземского, он оттеняет его концепцию меланхолии своей философией скорби, которую интерпретирует как способность человека почувствовать свое падение и одновременно возможность, искуплением греха, «вступить в первобытное свое величие» (X, С. 100). Весьма примечательно, что понятие скорби занимает в это время и Гоголя, постоянно пишущего в своих 
«Выбранных местах...» о необходимости «открывать новые недостатки в себе самом, с которыми нужно производить новые битвы» («Христианин идет вперед») ${ }^{8}$.

Этот мотив осознания человеком своего падения и необходимости нового взлета напрямую связывается Жуковским с мыслью об искуплении греха страданием. Преображение души есть результат внутреннего совершенствования человека, осуществляемого по воле Бога и самой личности. Таинственным образом душа освещается высшим

${ }^{8}$ Гоголь Н. В. Собр. соч.: В 8 т. М., 1984. Т. 7. С. 231.

знанием и новыми принципами отношения к себе, к миру, к Богу. Переломным моментом в совершенствовании человека признается приход к человеку веры в Христа, которую Жуковский называет «дитя скорби». Соответственно переломным моментом в жизни человечества Жуковский считает явление в мире христианства. Языческий мир представлен в статье с помощью пиршественных образов, но, чтобы подчеркнуть заблуждение древних, Жуковский использует страшный образ скелета, наряженного в блестящие «покровы». Образ «покрова» на «скелете жизни» передает самую суть опасной ошибки человечества, принимающего мир материи, мир без Бога («скелет жизни») за достаточную, полную, целостную модель жизни. Мотив покрова дополняется далее мотивом разоблачения, снятия завесы и открытия людям истины - их высокой природы, их низкого падения и «права на утраченное совершенство и блаженство, возвращенные искуплением» (X, С. 102). 
В связи с идеями покаяния и искупления, нашедшими развитие и в статьях «О внутренней христианской жизни», «Вера», «Таинство причащения» и др., Жуковский довольно часто переходит к трактовке темы смерти и бессмертия. Эти понятия оказались в центре его полемики с Вяземским о меланхолии. «В христианском мире, - утверждает Жуковский, - нет утрат», поскольку все, что происходит с человеком, является «сокровищем» для его души. Именно христианство, «победив смерть и ничтожество», изменяет внутренний мир человека. Прошедший через грехопадение, осознание своей греховности и раскаяние, исполненный скорбью по поводу своего несовершенства, человек способен выбрать путь самосозидания, приближающий его к Богу. Практически одновременно Жуковский развивает эту тему в «Странствующем жиде», где главный герой получает бессмертие в наказание за свои грехи. «Бессмертие мучительно для Агасфера, - пишет священник Д. Долгушин, - ибо оно делает его чужим в мире... Но главное - оно закрепляет греховное состояние его души. <...> Нужно сказать, что развивая подобным образом тему смерти и бессмертия, Жуковский сближается со святоотеческой традицией» ${ }^{9}$.

${ }^{9}$ Священник Д. Долгушин. Пасхальная тема в поэзии В. А. Жуковского: поэма «Странствующий жид». Новосибирск, 2000. С. 7-8. См. об этом также в работе: Канунова Ф. 3. Библейские мотивы в «Агасфере» Жуковского // Сюжет и мотив в контексте традиции. Новосибирск, 1998. Вып. 2. С. 122-132 (совместно с Е. В. Слепцовой).

\section{8}

Статья «О смерти», являвшаяся первоначально личным письмом Жуковского Н. В. Гоголю, построена на описании личного переживания автором смерти близкого человека. Именно вера в Христа, считает Жуковский, 
может обратить смерть-«бедствие», способное «раздавить душу», в «утешительный свет». Сквозь всю статью проходит важнейшая для автора евангельская идея смирения со смертью, понимаемой как преображение духовным (христианским) зрением физического акта. Смерть, в понимании Жуковского, это великая тайна, касающаяся кардинальной перестройки духовной жизни и для живых, и для умерших, поскольку она являет собой встречу со Спасителем «лицом к лицу». В этом плане данная статья продолжает ряд сочинений самого Жуковского (в стихах и прозе ${ }^{10}$ ) и входит в большой контекст русской литературы.

Центральной в поздних статьях Жуковского стала тема смерти Христа, его искупительной жертвы («О меланхолии в жизни и в поэзии», «О внутренней христианской жизни»). Весьма красноречиво и обращение Жуковского к образам, связанным с данной темой и комплексом идей, который она содержит. Это образы горы Елеонской, креста, чаши, хлеба и вина, Голгофы («О меланхолии в жизни и в поэзии», «О происшествиях 1848 года», «О внутренней христианской жизни», «Таинство причащения»).

В статье «О меланхолии в жизни и в поэзии» страдания и молитвы Христа на горе Елеонской ${ }^{11}$ названы «верховным изображением жизни христианина», выражением «преобразованного» верой в Христа человека - «во всей силе своего земного страдания и во всей божественности своего ведущего к небу смирения» (X, С. 104). Смерть Христа, заключающая в себе всю евангельскую концепцию человека, глубоко понимаемую и разделяемую Жуковским, воплощаемую им наиболее полно в позднем творчестве,

\footnotetext{
${ }^{10}$ Напр., «Письмо о кончине Великой княгини Александры Николаевны», которое было опубликовано в «Современнике» в
} 
1844 году, высоко оценено П. А. Плетневым, считавшим, что оно превышает «все, написанное им (Жуковским. - И. А.) в прозе» (цит. по кн.: В. А. Жуковский в воспоминаниях современников. С. 409), но не введенное писателем в состав своего собрания сочинений. «Письмо» было опубликовано в посмертном 13-м томе.

${ }^{11}$ Жуковский цитирует и контаминирует здесь стихи из молитвы Христа в Гефсимании (Мф. 26:38-39; Мк. 14:34, 36; Лк. 32:42).

осмысливается Жуковским и в статье «Таинство причащения». В причащении, считает Жуковский, «видимо и ощутительно в образе таинства повторяется перед нами и в нас самих искупительная жертва Иисуса Христа» (XI, С. 12), и потому «с человеком творится то же, что с разбойником на кресте, когда все преступное прошедшее одним словом: помяни мя, Господи, егда приидеши во Царствии Своем - приготовило вдруг всю грешную душу к очищению» (XI, C. 12).

Образ раскаявшегося уже во время казни разбойника, прощенного Иисусом и спасенного Им, искупающим своей смертью все грехи человеческие, от имени Бога («ответ на это слово (слово разбойника. - И. А.) был ответ вечного Бога на всю вечность: днесь со Мною будеши в раю», XI, С. 12), оказывается для Жуковского одним из главных символов, передающих суть смерти Христа. Жуковский подчеркивает с особой силой, что в этот трагический момент происходит великое чудо, повторяющееся в таинстве причащения: разрушается «стена, отделяющая человека от Бога, и он может, ведомый верою, с помощью благодати, переступить за сию границу» (XI, С. 13). Евангельские образы креста, чаши, хлеба и вина, связанные с мотивом смерти Христа, Жуковский осмысливает как «материальные образы нашей совести в акте покаяния» (XI, С. 13). Особое внимание обращено к образу Голгофы, который трактуется как сакральное пространство, где совершилось 
«один раз на всю вечность» чудо спасения, дополнившее чудо искупления до целого. Не случайно образ Голгофы включает в себя ряд других, из взаимодействия которых и создается представление об этом сакральном хронотопе. Прежде всего, следует назвать образ двери затворенной и отворяемой рукой Бога.

В статье «Воспоминание» поднимается тема вознесения Христа на небо после смерти. Мысли о жизни и смерти тесно переплетены здесь, с одной стороны, с религиозными идеями бессмертия души, а с другой - со знаменитой романтической «философией воспоминания» Жуковского. Рисуя свой сложный духовный, религиознофилософский опыт постижения смерти и бессмертия души, Жуковский опирается на собственное поэтическое творчество, извлекая из памяти давно написанные и переведенные стихи. Это и нашло отражение на уровне дискурса. Начавшись известнейшим стихотворением Жуковского «Воспоминание», статья продолжена рассуждением о двух его центральных

\section{0}

понятиях «нет» и «были», которое, в свою очередь, сменяется двумя зарисовками - о смерти королевы Луизы Прусской и о вознесении Иисуса Христа, переходящими вновь в не менее известное стихотворение «В ту минуту, когда ты в белой брачной одежде...»

Переданный только в Евангелии от Луки всего лишь одним стихом сюжет вознесения Господня, призванный подчеркнуть, с одной стороны, божественную природу Иисуса, a c другой - идею воскресения души ${ }^{12}$, Жуковский развивает в тончайший символикопсихологический этюд. Он построен на описании взгляда Иоанна, которым тот провожает «возлетевшего на небо» Спасителя. Один взгляд выражает сложнейшее внутреннее состояние любимого ученика Христа со всеми 
его тончайшими психологическими нюансами, со всей его искренней верой в то, что Создатель жив, с глубочайшим пониманием того, что есть жизнь и смерть Спасителя. «Переложение» сюжета о вознесении Господнем, представляющее собой единый религиознофилософско-художественный дискурс, приведем ниже полностью:

Иоанн, любимый ученик и апостол Спасителя, видел его возлетевшего на небо и глаза его подъяты к небу, приявшему все его блага - но в этих глазах не печаль разлуки, не томительное нетерпение оставить землю, но чувство спокойной, глубокой, покорной любви к улетевшему, как будто к присутственному. Он уже не на земле, но Он был на ней; своим преображением Он познакомил с таинством неба; но своею любовию, своим страданием познакомил с величием жизни; небесным Он озарил житейское, и не чудесное видение неестественного представляется взору молодого Иоанна: он спокойно наполнен святым воспоминанием, не томящим, не отлучающим от здешнего, но тихим, сладкозадумчивым, вполне удовлетворяющим душу; он смотрит на небо, на обитель удалившегося друга; не стремится туда, ибо земная жизнь оставлена ему в наследство, как благо, для совершения воли учителя; но верит с глубокою, мирною радостью, любит задумчиво и уповает без нетерпения! И все земное, радостное, печальное заключено для него в одном слове, во всем отражается и слышится одно слово: Спаситель твой жив! (XI, C. 24).

\section{5}

Через ряд статей Жуковского 1840-х годов пройдет мотив суда над Христом, творимого Пилатом. Наиболее полно

\footnotetext{
${ }^{12}$ «И когда благославлял их (учеников своих. - И. А.), стал отдаляться от них и возноситься на небо» (Гл. 24, ст. 51).
} 
он раскрывается в статье «О молитве». «Пересказ» библейской легенды суда над Христом, во время которого Пилат спросил Спасителя о том, «что есть истина», строится Жуковским на мысли о том, что Пилат и не подозревал, что «ответ на вопрос его заключается в самом вопросе, и, председая гордо на судилище», Пилат, по мнению Жуковского, «не узнает божественного откровения, ему предстоящего в образе этого Всемогущего Узника» (X, С. 77-78).

Пересказ этот следует за рассуждениями о возможности познать Бога:

Когда мы умствуем о Боге, мы, с своей точки во времени и пространстве, смотрим на вечное и неизмеримое глазами, привыкшими видеть одно преходящее и ограниченное... Чтобы постигнуть Бога и Его свойства, надлежит стать на Его место: иначе мы будем всюду видеть одни отрывочные, одна другой противоположные, следственно одна другую исключающие истины... Какое тогда прибежище останется уму... Вера в откровение. Откровение есть голос, слышимый с Божия места (X, C. 77).

Один раз только «истина сама явилась на земле глазам человека; и он ее видел без покрывала, и не узнал ее», и это было, как считает Жуковский, с Пилатом на суде над Христом. Один раз истина явилась и самому автору. Момент этот описан в приведенном ниже пейзаже, который следует за изложением евангельской легенды:

Однажды (это было в Висбадене) я шел перед вечером по берегу узкого канала; небо задернуто было синими облаками, из-под которых с чистого горизонта сияло заходящее солнце и золотило здания, деревья и зелень; этот яркий блеск составлял прекрасную противоположность с холодною мрачностью неба. Вдруг передо мною вода канала, дотоле спокойно неподвижная и стоявшая вровень с берегами (от плотины, которою канал был перерезан), быстро и с шумным кипением перелилась 
через край плотины в жерло водопровода (которым она далее текла под землею). На месте перелома, перед самым темным жерлом подземного свода, сверкала на солнце яркая, движущаяся полоса, и на этой полосе, от быстрого низвержения воды, взлетали бесчисленные, разной величины пылинками сияющие капли; одни подымались высоко, другие густо кипели на самом переломе, и все они на взлете и на падении яркими звездочками отделялись от темноты подземного свода, которым поглощалась вся влажная масса; мгновенное их появление, более или менее быстрое, вдруг прекращалось, уступая другому такому же, и все исчезали вместе с волною, их породившею, во тьме подземелья.

\section{2}

Это было для меня чудным символическим видением. С своего места одним взглядом я обнимал движение бесчисленных миров; эти светлые, мгновенные капли, эти атомические звезды, все, конечно, наделенные микроскопическими жителями (ибо здесь все преисполнено жизни), совершали каждая, как самобытный мир, свой круг определенный и каждый из обитателей всех этих минутных миров также совершал свой полный переход от рождения к смерти, - все это мне представлялось разом с той высшей точки зрения, вне того тесного пространства, на котором происходило видимое мною движение; я все мог обозреть в совокупности одним взглядом... не было ни настоящего, ни прошедшего, ни будущего; я разом видел начало и конец... Я, так сказать, смотрел... из вечности (X, С. 78).

Это художественный дискурс, сливающийся с философско-религиозным дискурсом о познании Бога, органично переходящим в переложение евангельского сюжета о Христе и Пилате, которое выполняет роль текста-посредника, являющего собой сложный синтез религиозного, философского и поэтического, личного и общего, чем и отличается выполненный Жуковским пересказ очень короткого фрагмента (по сути, объемом в 
одну фразу) из одного стиха (38-го) 18-й главы Евангелия от Иоанна («Пилат сказал Ему: что есть истина? И сказав это, опять вышел к Иудеям и сказал им: я никакой вины не нахожу в Нем»). Ср. у Жуковского:

Когда Спаситель стоял перед судилищем Пилата и Пилат спросил у него, употребив, как римлянин, язык Рима: Quid est Veritas? Что есть истина? - Господь не ответствовал. Но в ответе Его, если бы Он восхотел дать ответ, заключались бы все буквы слов вопроса с переменою только их порядка: est vir, qui adest. - есть муж, который предстоит. Истина есть Бог, а наш ум есть этот вопрошающий Пилат, который и не подозревает, что ответ на вопрос его заключается в самом его вопросе (понеже настоящий порядок ему не известен) и, председая гордо на судилище. Не узнает божественного откровения, ему предстоящего в образе этого Всемогущего Узника, которого скоро с самовластием беспощадным предаст поруганию и смерти (X, С. 77-78).

Весьма характерно, что, использовав все возможные способы передачи мысли и переживания минуты откровения истины (кроме указанных, автор еще прибегает к призыву вообразить ангела и сравнить его знание истины со знанием человека, пережившего мгновения откровения), Жуковский все-таки заканчивает текст серией вопросов, последний из которых соединяется еще и с многоточием.

И вопрос этот очень характерен: он о способности человека, которому открылась божественная истина, раствориться после этого «в блаженстве смирения» перед Богом.

Продолжением мотива суда над Христом для Жуковского являются размышления о Последнем Суде Божием. Так, смысловым центром статьи «История и историческая живопись» становится описание картины из 
берлинской кафедральной церкви Campo Santo, замысел которой принадлежал прусскому королю Фридриху Вильгельму IV. На картине изображается Суд Божий:

Всё небо в собрании. Верховный Судия, готовый произнести свой приговор, восседает посреди него на престоле славы; с одной стороны Богоматерь, с другой Иоанн Креститель, за ними все образы тех, для которых уже не может быть страшного суда и которые должны быть только его свидетелями, все представители минувшей судьбы человечества, все действователи древнего и нового завета, от Адама до святителей церкви, мучеников и царей блаженных. Пространство наполнено ангелами; они летают между небом и землею, перенося от людей молитвы к Богу, от Бога милосердие людям. Один стоит ангел, возвеститель суда; в руках его труба, готовая возгреметь наступление страшного часа; он ждет на то повелительного слова, и глаза его устремлены на Судию всевышнего, и вместе с ним все небо смотрит на этого Судию, преисполненное ожидания. Но слово его еще не произнесено; над землею таинственно простираются облака, сокрывающие от нее происходящее в вышних. Когда наступит этот час, кто знает? Для тех, кто на небеси, он уже настал, ибо они в вечности, где все сливается в настоящее; для земли он еще в неведомом будущем. Состояние этой ожидающей, но покровенной мраком неведения земли, прекрасно и трогательно выразил царственный живописец, представив на ней самого себя с семейством и с современниками, молящихся и ожидающих (XI, С. 29-30).

Описание картины о конечных судьбах людей, выполненное Жуковским, есть ответ на религиознофилософский и вместе с тем эстетический вопрос, предваряющий это описание:

Как выразить в одно время и небо, и рай, и ад, и землю?

Характерно, что первое слово этого описания - всё. Оно лейтмотивом пройдет через словесное полотно Жуковского: все образы, все представители, все 
действователи, всё небо. Дискурс движется здесь от важнейшей поэтической традиции Жуковскогоромантика, связанной с философией универсализма, к переживанию целостности бытия, уже

184

религиозному в своей основе. Картина, в описании Жуковского, запечатлела прежде всего эту универсальность момента, неразрывность гибели и возрождения, начала и конца, времени и вечности, судьбы одного человека и человечества.

Особое внимание писатель уделяет пространственному построению картины, точно отразившей сакральность и целостность построения мира: земля - небо, в центре Верховный Судия, с одной стороны Богоматерь, с другой - Иоанн Креститель, между небом и землею летают ангелы, «перенося от людей молитвы к Богу, от Бога милосердие людям». В чистой одновременности запечатлено грехопадение, раскаяние, искупление, прошлое, настоящее, будущее как лики вечности («все представители минувшей судьбы человечества, все действователи древнего и нового завета, от Адама до святителей церкви, мучеников и царей блаженных», а также «живописец... с семейством и с современниками», молящимися и ожидающими).

Живописный мир картины, подчеркивает Жуковский, населяют образы конкретных людей, связанных с конкретным историческим временем, но всех объединяет общая ситуация вечности, высшей оценки «не умирающих дел души». Отметить это для Жуковского принципиально, ведь описание картины в его статье есть характеристика особенностей исторической живописи в еe соотношении с историей. Таким образом, Жуковский акцентирует в своем описании картины переданную живописцем идею бытия, живущего по линии 
вневременного потустороннего восхождения к идеалу (или, наоборот, отхода от него) и по линии живого исторического времени. Этот синтез и является главным нервом религиозного философствования самого Жуковского.

Обращая внимание на необычность и даже гениальность замысла Фридриха Вильгельма IV, Жуковский отмечает специально тот факт, что героем картины, изображающей Суд Божий, становится и сам «живописец» со своим семейством. Для автора статьи, может быть, самым важным в описываемом им полотне является именно это соединение внутренней личной судьбы и вечного общечеловеческого бытийного сюжета. Здесь принципиально для Жуковского особое выделение некоторых деталей картины. Взгляд Художника, с одной стороны, уникален: он «презирает» с земли, «покровенной мраком неведения», внутреннюю

суть происходящего «там», с другой стороны, его взгляд, как у всех - «молящий и ожидающий».

Описание картины органично переходит в своего рода продолжение предшествующего ему философствования, которое практически подхватывает вопрос, открывающий словесное полотно Жуковского:

Как выразить в одно время и небо, и рай, и ад, и землю? $<\ldots>$ Этой картины одной довольно... Она представляет весь ход христианства, которого эпохи соединены в одно великое соприсутствие; она говорит стоящим во храме: «перед вами все, что было, и все, что будет: падение, искупление и последний час временного, после которого наступит вечность; но когда наступит она, вам неизвестно. Бодрствуйте - и молитесь» (XI, С. 30). 
Так, философский дискурс сменился в статье художественным, чтобы затем живописно-словесные образы перевоплотились в понятия.

В статье «О происшествиях 1848 года» проблема Суда Божия рассматривается параллельно вопросу о суде истории. Признавая роль последнего в жизни общества, Жуковский все-таки настаивает на том, что «листам истории», «минутным и бренным», принадлежат только «минутные, земные события».

Народы и империи, их начало, величие и разрушение... не иное что, как призраки; одно посреди них существенно и живо: бессмертная душа наша.

Именно «не умирающие дела души», считает Жуковский, «принадлежат листам той вечной книги Божией, которая некогда разогнется на последнем суде Его» (X, С. 111). Разделяя «земные события» и «дела души», автор проводит довольно четкую границу: история «одобряет успех или опорочивает неудачу», «судит один Бог» (X, С. 111; выделено нами. - И. А.). Оценка прошедших событий будущими поколениями явно противопоставляется Суду Божию как одна грань целого всему целому.

6

Лейтмотивом через всю святую прозу Жуковского проходит тема Евангелия как священной книги, из которой исходит «голос Спасителя» (X, С. 74), и проблема Слова Божия («Смерть», «О молитве», «О меланхолии», «О происшествиях 1848 года», «Таинство причащения»). Евангелие повсюду трактуется Жуковским как книга истины, «без согласия ума доказанной верою» (X, С. 76). Эта книга о земной 
жизни и смерти Христа, в представлении Жуковского, является для человека главной, не давая ему впасть в уныние и отчаяние, укрепляя веру в верующем и еще не пришедшем к вере. Евангелие осмысливается Жуковским своеобразным «посредником» между человеком и Богом, «перед которым мы должны не обинуясь раскрыть нашу душу» (XI, C. 13).

Много и глубоко рассуждает Жуковский о Слове Божием. Для него это, безусловно, сакральная субстанция, в которой содержатся «все возможные утешения, данные наперед человеку на все беды житейские» («Вера»; XI, С. 5). Вместе с тем Жуковский видит определенную общность между Словом Божиим и словом поэтическим. Связующим звеном здесь оказывается Откровение. С точки зрения Жуковского, слово поэта рождается «не нашею волею», оно результат откровения, награждающего «нашу неутомимость» в его «искании» (XI, С. 19). «Слово упрямо и причудливо: его нельзя взять силою; оно прячется от нас, когда мы его ищем и кличем, и вдруг нам является там, где мы найти его не ожидаем. Слово есть откровение»- читаем в специально посвященной этим проблемам статье «Философический язык», которая входила во второй цикл тома «Философия» (XI, С. 21). Жуковский утверждает здесь, что поэтическое слово имеет две субстанции - внутреннюю, духовную, и внешнюю, «звучную». «Ясность выражения зависит», по мнению поэта, от «сродства, от совпадаемости слова звучного со словом духовным» (XI, С. 20).

Такое понимание слова основывается у Жуковского на его представлении об искусстве вообще. В томе «святой прозы» предполагался отдельный цикл фрагментов «Искусство». Его открывала программная статья «Об изящном искусстве». Именно здесь поэт формулирует свое понимание искусства, его источника, цели, что 
сейчас уже представляется филологами незыблемым фундаментом романтической эстетики.

Искусство - поэзия в разных формах; источник искусства - творческая сила человека, посредством которой он посреди творения Божия другими средствами творит то же, что в глазах его сотворено природою; его материалы для творения суть: слово, звук, краска, твердая материя. Цель искусства - не иное что, как самое сие создание, которое в то же время должно быть и создание изящное, то есть пробуждающее в душе сладостное ощущение красоты (XI, C. 27).

В очередной раз Жуковский подчеркивает родство искусства и религии. Оно зиждется на творении, созидании «истины идеальной», которая и есть, по Жуковскому, красота «в широком смысле», означающая великую целостность, синтез духа и материи - «не одно ощутительное сходство выражения с выражаемым, но и соединение с ним того, что неощутительно, что единственно существует в душе человеческой, постигающей нечто высшее, вне видимой материальной природы существующее, и свойственное ее божественной природе» (ХІ, С. 27).

$\mathrm{C}$ особым вниманием Жуковский рассматривает проблему выражения словом мыслей о Боге и религиозных переживаний человека. Здесь мнение поэта вполне определенно:

...нам не только не можно, но и не нужно, и даже не должно искать таких доказательств бытия Божия, какими убеждаемся мы во всякой другой доступной рассудку истине: необъятность полной идеи Бога не может втесниться в нашу человеческую мысль, в наше человеческой слово; и наши усилия заключить ее в эти пределы необходимо должны ее исказить и запутать (XI, C. 3). 
Более того, Жуковский считает, что именно «наше бессилие схватить умом необъятное и выразить словом невыразимое» и есть «убедительнейшее доказательство» существования Бога. Поэтому «философическим языком» Жуковский доказывает, что «иной философии быть не может, как философия христианская, которой смысл: от Бога к Богу. Философия, истекающая из одного ума, есть ложь. Пункт отбытия всякой философии, point de depart, должно быть Откровение» ${ }^{13}$.

Особого внимания в связи с вышесказанным заслуживают цитирование Жуковским Евангелия и его попытки комментировать некоторые евангельские стихи. Целый ряд поздних статей начинается с вопрошания. «Будьте подобны младенцам, ибо их есть царство небесное, сказал Спаситель, указывая на детей, Его окружающих». «Что значит это слово?»- спрашивает автор в статье «Промысл» (XI, С. 9). И далее он предлагает свою интерпретацию слов Спасителя о младенцах (Мф. 18:3; Мк. 10:13-16; Лк. 18:15-17). Комментарий Жуковского, довольно далекий от богословского, весь построен на образе младенца. Не останавливаясь C. 18.
188
на толковании предшествовашего фразе Христа о младенцах и Царствии Божием спора учеников Иисуса о том, кто больше достоин Царствия Небесного, Жуковский сосредоточивается на обрисовке детского характера. В нем автор подчеркивает невинность перед законом, безусловную покорность родителям, основанную на любви, «беззаботность о завтрашнем дне», «незлобие».

${ }^{13}$ Переписка В. А. Жуковского с А. С. Стурдзою. Одесса, 1855. 
Христианин, с точки зрения автора, и должен стремиться сохранить в себе, при полном знании всех тягот житейских, указанные качества младенца. Эта идея, переданная в статье сочетанием разных дискурсов, отличается чрезвычайной нравственной красотой и чистотой, полностью соответствуя тому образу, с помощью которого она воплощена в тексте. Из рассуждения о невинности младенцев, их покорности отцу органично вытекает подробный, слово за словом, комментарий молитвы «Отче наш» (XI, С. 9). К комментарию этой молитвы поэт обращается и в статье «О молитве».

Вопросом открывается статья «Закон и грех»: приведя цитату из Послания к римлянам святого апостола Павла («Без закона грех мертв. Я жил некогда без закона; но когда пришла заповедь, то грех ожил, а я умер»Гл. VII, ст. 8-10), Жуковский спрашивает:

Как понимать слова апостола? Что значит здесь слово смерть греха и смерть человека? (XI, С. 10).

Отталкиваясь от семантики слова: «Грех в одном смысле есть греховность, то есть наша, врожденная нам наклонность грешить; в другом смысле грех есть действие греховности, поступок, нарушающий заповедь Божию» (XI, С. 10), Жуковский развивает этот тезис, обращаясь к проблеме свободы и необходимости в жизнедеятельности человека и их соотношения с верой в Христа и его заповеди. Примеры можно продолжать.

Некоторые евангельские стихи буквально не давали покоя Жуковскому на протяжении нескольких лет. Таковы, например, слова Спасителя, переданные евангелистом Иоанном Богословом:

Да не смущается сердце ваше; веруйте в Бога и в Меня веруйте (Гл. 14, ст. 1). 
Впервые появившись в одной из его записных книжек (1844-1845), они вошли в целый ряд статей Жуковского. Ими открывается центральный фрагмент статьи «Вера». Практически не учитывая богословское толкование этих

слов $^{14}$, Жуковский наполняет фрагмент столь характерной для его поздней прозы исповедальностью и связанной с этим «поэзией мысли». Утверждение «В этом слове (имеются в виду рассматриваемые нами слова Спасителя. - И. А.) все возможные утешения, данные наперед человеку на все беды житейские» органично переходит в размышление философско-психологоэтического плана:

Но как приобресть веру? Умом я убежден, что вера есть венец души человеческой, ее прямой путь к Богу; вера - мать любви; любовь - возможное совершенство души человеческой. Но как дать себе эту веру? Как дойти до того, чтобы она была все, во всем и всегда?

Эта серия отнюдь не риторических для Жуковского вопросов переходит в художественный дискурс, призванный изобразить внутреннее состояние автора, философствующего о вере и путях к ней:

Если сердце сухо, как русло ручья иссякшего, если оно холодно, как железо, и нечувствительно, как камень - кто оживит его для веры? Наша воля не имеет этого всемогущества. Вера есть ей неподвластное событие во внутренности души нашей ${ }^{15}$ (XI, С. 5).

Стих 1 из главы 14 Евангелия от Иоанна Жуковский вводит и в статью «О внутренней христианской жизни» (1846). Здесь призыв Иисуса Христа «Да не смущается сердце ваше...» напоминается читателю как резюме авторских рассуждений об одном из самых трудных разделов религиозной философии - о теодицее. 
Рассуждая о таком страдании, цель которого непонятна человеку, Жуковский словами Спасителя утверждает, что существование в мире зла не может быть доказательством его безбожия. Именно в страдании, смысл которого скрыт для человека, он должен опереться на Бога, укрепившись в своей вере.

Парафраз ст. 1-3 из главы 14 Евангелия от Иоанна встречаем и в статье «О меланхолии в жизни и в поэзии».

\footnotetext{
${ }^{14}$ В Библии, как известно, речь идет о смущении апостолов крайне кратким разговором Господа с Петром. Кроме того, всем апостолам оказались неясны слова Христа о какой-то ожидающей их борьбе. Видя это смущение, Иисус Христос призывает апостолов верить, несмотря на все то, что смущает их в данный момент. См.: Толковая библия. 1987. Т. 3. С. 446.

${ }^{15}$ Об этом же Жуковский писал Гоголю в письме от 20 января (1 февраля) 1850 года: «"Да не смущается сердце твое!" Так думается всегда, но не так чувствуется в некоторые минуты, которые своею тревогою сокрушают душу» ( XII, 115).
}

190

Как неоспоримый аргумент своей правоты, Жуковский вводит его в свою полемику с Вяземским, о которой уже шла речь выше. Вновь и вновь выступая против взгляда на жизнь как на «лоскуток чего-то, как на программу, как на лотерейный билет», следствием чего является тоска и меланхолия, Жуковский утверждает иной подход к жизни, освещенный верой и не позволяющий в силу этого заключать «эту жизнь в тесные пределы праха»:

И есть о чем тут тосковать тому, перед кем мерещится вдали один только этот сон, как итог, как последний результат жизни; эта вся тоска особенно состоит в том, что, засыпая, он не знает, где и как проснется; не знает потому, что смотрит на жизнь сквозь черное стекло скептицизма, а не при свете истины Спасителя, который говорит: «Да не смущается сердце ваше! Веруйте в Бога и в Меня веруйте; в дому Отца Моего 
обители многи суть; иду уготовать место ваше, да и вы там будете, где Я буду» (X, С. 105).

Интересно, что именно этими словами поддерживает Гоголь Жуковского и в его духовных исканиях, и в его новых писательских замыслах, означавших во многом новый поворот творчества. Не случайно он дважды повторяет свой парафраз указанного евангельского стиха в статье «Просвещение», которая, что общеизвестно, первоначально создавалась как письмо Жуковскому:

Брат, благодарю за все! <..> Веруй, и да не смущается твое сердце!

\section{И ниже:}

...не меньше добра, если еще не больше (по сравнению с «Одиссеей». - И. А.) принесут те труды, на которые навел тебя сам Бог и которые ты держишь покуда разумно под спудом. В них окажется также потребность общая. Не смущайся же и твердо гляди вперед! ${ }^{16}$

Гоголь говорит здесь о задуманном Жуковским томе «святой прозы», работе над которым оба придавали большое значение. Жуковский же, в свою очередь, написал данные слова Иисуса Христа из его прощальной беседы с учениками на обороте записной книжки, которую он подарил Гоголю 8 (20) окт. 1846 года во Франкфурте.

К цитированию и толкованию слов из Соборного послания св. апостола Иакова: «...вера, если не имеет дел, мертва сама по себе» (Гл. 2, ст. 17) Жуковский также обращался неоднократно в связи с важнейшей для него

\footnotetext{
${ }^{16}$ Гоголь Н. В. Собр. соч.: В 8 т. Т. 7. С. 250.
} 
проблемой «живой, деятельной веры». Прежде всего, следует обратиться к статье «Вера», во многом построенной на различных контаминациях указанного евангельского высказывания. $\mathrm{He}$ принимая «умозрительной философии», которая, по словам Жуковского, «идет своим путем рядом с религиею, и часто врозь с нею», писатель отдает предпочтение «философии христианской» во многом потому, что «в первой умозрения принадлежат особенному метафизическому миру и отдельны от жизни; в последней умозрения входят в деятельную жизнь, с нею сливаются, и дают ей, в самых простых событиях ежедневного, полноту и глубокую значительность» (XI, С. 19; курсив мой. - И. А.). В связи с этим Жуковскому представляются нелепыми идеи изначальной предопределенности человека к спасению или к гибели, возможность «веры без дел». Отстаивая «живую веру», которая напрямую связана у Жуковского с идеей жизнестроения, многое определявшей в его поздней эстетике и творчестве, писатель настойчиво подчеркивает и обратную сторону данной проблемы:

...вера без дел мертва есть. Но и дела без веры мертвы суть. Дела без веры составляют что-то несвязное, нецелое, не имеющее образа. Дела благие, при самом благодетельном их действии на душу, всё оставляют ее в... состоянии несовершенства (XI, С. 4).

Развивая положения статьи «Вера» в следующей за ней статье «Промысл», Жуковский рисует образ праведникахристианина, наградой которого уже в земной жизни является не «плата по таксе за каждое особенное дело, а общая награда, заключающаяся в самом состоянии души, во внутреннем мире ее, заговаривающем беды житейские» (XI, С. 9). И вновь Жуковский сосредоточивается на проблеме «дел без веры», которые 
он приравнивает к «действиям автомата». Только вера, считает автор, придает «делам» человеческую суть, оживляя душу человека, возвращая ему «утраченное подобие Божие» и сообщая его деятельности сакральный, вечный смысл, вливающий еe в «одну общую гармонию» ${ }^{17}$.

На цитировании слов Христа о необходимости поиска всеми Царства Божия и правды Его (Мф. 6, 33; Лк. 12, 31)

\footnotetext{
${ }^{17}$ В статье «О внутренней христианской жизни» Жуковский также ставит проблему «живой веры». Утверждая, что «живая вера в Бога» невозможна без веры в Христа, он продолжает здесь свои размышления о постижении Бога через воплотившегося в Нем Сына Божия, о чем у нас уже шла речь выше (см. раздел 1).
}

192

Жуковский строит портрет И. Радовица в одноименной статье 1850 года. В этом биографическом очерке поэт наиболее полно раскрывает свое понимание Царства Божия, поиски которого, как и у Гоголя, связываются с нравственно-этическими поисками человека, подкрепленными верой ${ }^{18}$. Евангельские стихи, которые, кстати, цитирует и Гоголь в статье «Русский помещик» ${ }^{19}$, в статье Жуковского служат своего рода резюме в авторском описании жизни Радовица: «...ищите прежде Царствия Божия и правды Его и все остальное приложится вам»; «это правило проникло все его (Радовица. - И. А.) мысли и все его действия ${ }^{20}{ }$ (XI, C. 56).

К этим же идеям «правды Божией» и Царствия Божия Жуковский обращается в статьях общественнополитического плана «О происшествиях 1848 года», «Русская и английская политика». Противопоставляя материальному благополучию общества как цели внутренней политики европейских государств 
достижение всеобщего нравственного благоденствия, Жуковский пишет:

...истинное благоденствие народов не в распространении границ, не в материальном нагромождении богатства, а в богатстве нравственном... т. е в сохранении правды Божией. Теперь настало время переменить основные правила политики и опереть ее не на языческих понятиях метафизического государства, а на христианских понятиях Царства Божия, в котором нет врагов, а есть один союз народов для общего благоденствия. <..> Настала пора воздвигнуть знамя любви христианской и соединиться под ним в одну рать для охранения общего благоденствия (XI, С. 45).

Для этого необходимо только одно, считает Жуковский:

...догадаться, что существующий Бог есть Бог живой, а не пантеистический призрак.

Как уже указывалось, Жуковский неоднократно обращался к размышлениям о молитве «Отче наш», которой

\footnotetext{
${ }^{18}$ И. А. Виноградов и В. А. Воропаев приводят воспоминание Е. А. Хитрово из дневника, в котором рассказывается, как Гоголь в январе 1851 года в Одессе читал у Репниных проповедь митрополита Московского Филарета на стих «Ищите Царствия Божия...». При этом Гоголь говорил: «Когда внутренно устроен человек, то у него все ладится. А внутренно чтоб устроенным быть, надобно искать Царствия Божия, и все прочее приложится вам» (см.: [Гоголь, 2001, c. 497]).

${ }^{19}$ См.: Гоголь Н. В. Собр. соч.: В 8 т. Т. 7. С. 292.

${ }^{20} \mathrm{Cp.}$ у Гоголя: «О главном только позаботься, прочее все приползет само собою. Христос недаром сказал: "Сия вся всем приложится"» (Там же).
}

Христос научил своих учеников в Нагорной проповеди. Прежде всего, характерно понимание Жуковским самого 
процесса молитвы, который толкуется в статье «О молитве» как вступление «вечного Бога... в братство с минутным жителем земной пылинки», как покорение божественной благости «силе человеческого слова» (X, С. 77). Утверждая молитву как непосредственное общение верующего с Богом, автор заявляет важнейшую и для него, и для его адресата проблему, имеющую непосредственные выходы в гносеологию, эстетику и психологию творчества, - проблему магической силы слова, способного выразить душу его произносящего. Молитва, по мысли автора, это форма самого непосредственного выражения внутреннего состояния человека, это своего рода высшее духовное творчество личности. Как известно, именно такое освоение молитвенного слова было характерно для романтической духовной лирики ${ }^{21}$.

Вместе с тем ориентация на библейскую традицию приводит Жуковского к трактовке молитвы как религиозного таинства, хотя и здесь вырабатывается своя концепция и расставляются свои акценты. В первую очередь, через молитвенное слово, обращенное к Богу, утверждается в статье, совершается таинство смирения, то есть важнейший акт внутреннего преображения человека, свободно вверяющего себя Божьей воле. Молитва, по Жуковскому, есть акт «самоотвержения» и, следовательно, самосовершенствования:

...самоотвержением мы приходим к молитве, а молитва, будучи высшею степенью самоотвержения, усиливает его в душе нашей и им нас совершенствует (X, С. 79).

Интересно в связи с этим отметить, что в статье возникает образ младенца как символ абсолютной покорности верующего во время молитвы. В представлении Жуковского, полученная от самого 
Спасителя возможность молиться есть доказательство любви Божьей к человеку.

В связи с таким пониманием молитвы интерпретируются все стихи «Отче наш» ${ }^{22}$, и не только в статье «О молитве»,

\footnotetext{
${ }^{21}$ Сам Жуковский, как известно, не раз обращался к молитвенной лирике, жанрообразующим фактором которой выступала именно духовная природа молитвы («Молитва детей», две «Молитвы русского народа», «Stabat Mater», «Елизавете Рейтерн»).

${ }^{22}$ Переложение этой молитвы было сделано рядом современников Жуковского (Кюхельбекером, Батеньковым). См.: Афанасьева Э. М. Молитвенная лирика декабристов // Проблемы литературных жанров. Материалы IX Международной науч. конф. Томск, 1999. Ч. 1. C. $141-144$, а также другие ее работы.
}

\section{4}

но и в статьях «Промысл», «О внутренней христианской жизни» ${ }^{23}$. При всей своей простоте, доступности даже малому ребенку эта молитва становится основой для глубоких рассуждений Жуковского о святости имени Божьего, о сути Царствия Божия, в котором «все живущее и мыслящее совокупно отвергнется от себя и... каждая отдельная воля сольется со всеми другими в одно всеобщее повиновение воле верховной» (X, С. 80). Жуковский рассуждает и о понятии «хлеб насущный», толкуя его, с одной стороны, в соответствии с евангельским представлением как о всякой пище, нужной для существования человека, и телесной, и духовной. С другой стороны, в духе общей идеи названных статей идеи самоотвержения человека перед лицом Бога Жуковский, во-первых, уточняет круг духовных потребностей личности («чистые мысли и чувства, спокойствие в присутствии беды и горя, терпение в испытании, память долга в решительную минуту выбора воли») и, во-вторых, сводит их к общему знаменателю: 
...произвольному... преданию себя в хранящую волю Бога (X, C. 80).

Вместе с тем, толкуя стих «Не введи нас в искушение, но избави нас от лукавого», Жуковский делает акцент на свободной воле человека, которая дарована ему Богом и которая может придавать его поступкам как доброе, так и злое направление. Одним словом, молитва «Отче наш» интерпретируется Жуковским в связи с основополагающей для него нравственно-философской проблемой внутренней свободы человека, проявляемой и в жизни, и в искусстве в соотнесении с волей Бога. Нервом этой молитвы становится идея синтеза.

Интересно поставить рядом толкование этой молитвы Гоголем в «Размышлениях о Божественной литургии», которые он, как вспоминает доктор А. Тарасенков, «окончательно отделал» незадолго до смерти, «хотел сделать это сочинение народным» ${ }^{24}$, чтобы, как подчеркивается в «Предисловии», утвердить «в голове читателя порядок

\footnotetext{
${ }^{23}$ Стих «Да будет воля Твоя» рефреном проходит и через статью «О внутренней христианской жизни», в которой каждый фрагмент за канчивается этими словами.

${ }^{24}$ Тарасенков А. Т. Последние дни жизни Н. В. Гоголя. СПб., 1857. C. 6 .
}

всего» ${ }^{25}$. На первом плане в сопроводительном слове Гоголя, и в этом он, прежде всего, близок Жуковскому, морально-психологические и философские темы, а главное - мысль о «всеобъятности» этой молитвы:

Все обняла собою сия молитва, и в ней все заключилось, что нам нужно.

И далее: 
Так все заключает в себе и все объемлет собою сия молитва, которою молиться научила нас сама Премудрость Божия ${ }^{26}$.

$\mathrm{He}$ случайно у Гоголя тоже появляется мотив младенческого сердца, младенческого пения, младенческих звуков молитвы «Отче наш», «лобзающих самую душу» ${ }^{27}$.

Характерно, что в статье «О молитве» Жуковский поставит проблему эстетического плана - «нагота бедного языка человека», вынужденного употреблять те же слова, «какими выражается наша ничтожность», «для выражения неизглаголанности Божьей» (X, С. 77). Границы человеческого слова расширяются до бесконечности только в минуты откровения. Таково молитвенное слово, произнесенное с верою в Бога, и близкое к нему слово художника. И то, и другое оборачивается спасением, утешением для человека, так как «все для нашей ограниченности несогласимые противоречия исчезают» (X, С. 76).

В статье «Две сцены из "Фауста"» Жуковский специально останавливается на толковании первого стиха первой главы Евангелия от Иоанна «В начале было Слово». По справедливому мнению Ф. З. Кануновой, освобождающему нас от необходимости подробного анализа, в этом комментарии выражена суть концепции слова Жуковского, которая, в свою очередь, связана с его пониманием искусства как «пересоздания собственными средствами» «создания Божия». Именно с сакральным отношением Жуковского к слову, которым пронизана не только его статья о «Фаусте», но и целый ряд других, связывают исследователи и знаменитую эстетику и поэтику «невыразимого», сформулированную теоретически и реализованную на практике первым русским романтиком $^{28}$. 
${ }^{25}$ Гоголь Н. В. Размышления о Божественной литургии. М., 1990. C. 17.

${ }^{26}$ Барабаш Ю. «Ныне отпущаеши...» // Гоголь Н. В. Размышления о Божественной литургии. С. 10 [Вступ. ст.].

${ }^{27}$ Там же. С. 53.

${ }^{28}$ Из дореволюционных см., прежде всего, работу А. Н. Веселовского «В. А. Жуковский. Поэзия чувства и "сердечного воображения"» (СПб., 1904). Из современных см. исследования Ф. 3. Кануновой, в частности: Канунова Ф. 3., Айзикова И. А. Нравственно-эстетические искания русского романтизма и религия. Гл. I «Вводная». См. также нашу монографию «Жанрово-стилевая система прозы В. А. Жуковского». Гл. 4 (Томск, 2004). О цитировании Жуковским ст. 42, 43 гл. 23 из Евангелия от Луки, ст. 6 гл. 14 из Евангелия от Иоанна, а также стихов из молитвы Христа в Гефсимании уже было сказано в данной статье (см. разделы 1,4$)$.

196

Таким образом, дух Нового Завета пронизывает всю позднюю прозу Жуковского, которая зовет читателя в сферы духовного мира человека, в сферы вечных истин и ценностей без отрыва от реальности, от проблем современной истории, современного общества, искусства. Все это создавало новое качество сочинений Жуковского, обеспечивая их выход к универсальным, метафизическим смыслам в рамках художественного слова, объясняя во многом сам факт его решительного поворота к эпосу, к прозе, определявшего многие перспективы русской литературы в целом. 